\title{
Paternalisme industriel - jedna z odpovedí na sociálnu otázku
}

\author{
JAKUB ŠTOFANÍK*
}

Paternalisme Industriel - One of the Answers to Social Question

\begin{abstract}
The article pays attention to industrial paternalism as one of the models of employer-labour relations that have emerged during the 19th century. It focuses in particular on the French environment, in which industrial paternalism strongly resonated and where we can find many of its important actors. The study brings on the light its precursors and inspirations in the concept of patronage of Frédéric Le Play as well as the interactions between state, entrepreneurship, and working class. The text introduces main characteristics of this managerial approach in the historical context of the end of the 19th and first half of the 20th century with the changing nature of French industry and massive immigration of labour force. It analyses historiographic production devoted to this phenomenon and offers various ways of its interpretation.
\end{abstract}

Keywords: industrial paternalism; social question; France; historiography

DOI: $10.14712 / 23363525.2020 .8$

Proces industrializácie so sebou priniesol množstvo nových výziev a potrieb. Postavenie robotníctva, vztahy medzi vlastníkmi podnikov a ich zamestnancami, zamestnancami navzájom, otázky ubytovania, vzdelávania, zdravotnej starostlivosti či podpôr rodín sa tak dostávali stále viac do popredia. V̌̌etky tieto prvky sa pritom podielali na mobilizácii robotníctva, ale aj na konkurenčnom boji podnikov o kvalifikovanú pracovnú silu. Tá stála v centre záujmov vlastníkov vel'kých priemyselných koncernov a do značnej miery definovala schopnost' prežitia firmy. Vo francúzskom prostredí sa v priebehu 19. storočia vyvinul špecifický model vztahov medzi vedením podnikov a robotníctvom, ktorý sa následne uplatnil aj v realite priemyselných podnikov v 20. storočí. Išlo o priemyselný paternalizmus, ktorý v období 19. a prvej polovice 20. storočia prešiel niekolkými štádiami. Tento článok si kladie za ciel' priblížit jednak východiská tohto modelu vztahov, jeho významných aktérov, ako aj historiografické debaty posledných tridsiatich rokov premýšlajúce jeho definíciu i celkovú interpretáciu.

Korene a inšpirácie priemyselného paternalizmu sú naozaj mnohovrstevnaté a niekedy až navzájom protichodné. Siahajú k úvahám politickej ekonómie 18. storočia, hlavne do prostredia fyziokratov, i k mladším inštitucionálnym štruktúram reprezentovaným Société d’encouragement pour l'industrie nationale (Spoločnost’ na podporu národného priemyslu). Tá vznikla v roku 1801 s jednoznačným cielom pozdvihnút francúzsky priemysel zaostávajúci za Anglickom v dôsledku revolučných nepokojov a vojen. Vel'kú pozornost̉ pritom venovala nielen zavádzaniu nových technických výdobytkov, ale aj správe tovární, vztahu k robotníctvu a vzdelávaniu nastupujúcich generácií. V tejto oblasti sa Spoločnost̉ na podporu národného priemyslu zamerala na školy, ktoré by pripravovali na prácu samotné robotníctvo a nie

* PhDr. Jakub Štofaník, Ph.D., Masarykův ústav a Archiv Akademie věd ČR, v. v. i., Gabčíkova 2362/10, 18200 Praha 8. E-mail: stofanik@mua.cas.cz 
len inžinierov a špecialistov. V úvahách o priemyselnom paternalizme boli badatelné aj inšpirácie hodnotami liberalizmu, hlavne v ponímaní privátneho angažovania sa jednotlivcov. Malo prebiehat bez toho, aby bol výrazne zapojený štát, voči ktorému boli priemyselníci silne ostražití. Nezanedbatelnú rolu hrala i filantropická tradícia ešte z prostredia aristokracie, ktorú si osvojili nové elity, ako aj silné náboženské poňatie lásky k blížnemu, charity a povinnosti voči chudobným a odkázaným členom spoločnosti [Doria 2014: 19, 27-28].

Výraznou postavou zúčastňujúcou sa debát o sociálnej otázke sa stal od polovice 19. storočia francúzsky inžinier, sociológ a ekonóm Frédéric Le Play (1806-1882). Pôvodne inžinier metalurgie sa vdaka svojím cestám a vel’mi koncentrovanému štúdiu životných podmienok robotníctva profiloval nielen ako jedna zo zakladatel'ských osobností francúzskej sociológie a priekopník zúčastneného pozorovania, ale aj ako výrazný teoretik vztahov medzi vedením podnikov a robotníctvom [Savoye 1994]. Vychádzal pritom z kritiky režimu manufaktúr a vo svojej práci La Réforme Sociale en France (Sociálna reforma vo Francúzsku) z roku 1867 predložil aj vlastné chápanie prístupu patronage, ktorý sa mal stat základnou formou správy pracovnej sily. Le Play chápal patronage ako dobrovolné puto prospechu a náklonnosti medzi robotníkom a vlastníkom. Práve táto väzba mala nahradzovat' nútené vztahy medzi aktérmi typické ešte pre obdobie Ancien régim [Le Play 1867: 413]. Patronage mala predstavovat integratívny prvok - siet’ vzájomných vztahov a záväzkov medzi robotníkom a vlastníkom, ktorý prispeje k pokojnému prechodu k masívnej továrenskej výrobe [Lamanthe 2011: 69-72]. Značného vplyvu sa Le Playovi dostalo hlavne po francúzsko-pruskej vojne a potlačení Parížskej komúny, kedy si široké kruhy uvedomili naliehavost', aktuálnost' i výbušnost' sociálnych problémov [Savoye, Cardoni 2007: 179]. Myšlienkový odkaz Le Playa v oblasti výskumu robotníckej každodennosti i spoločenských vztahov sa následne šíril prostredníctvom jeho pokračovatelov, medzi ktorými boli akademici, ale aj riaditelia vel'kých závodov ako Émile Cheysson (1836-1910) alebo Robert Pinot (1862-1926). Sociologické metódy a názory Le Playa si osvojila i katolícka cirkev, ktorá ich vtelila do vlastného formujúceho sa sociálneho učenia. Katolíci aktívni na sociálnom poli tak získali odbornú oporu proti pozitivistickej vede artikulovanú v duchu dobovej sociológie i uistenie, že charitatívne pôsobenie už nie je v podmienkach priemyselnej spoločnosti dostačujúce a v prostredí robotníctva treba vyvinút ovela cielenejšiu aktivitu [Štofaník 2017: 33]. Náboženské motivácie a jasný záujem o riešenie sociálnej otázky v tomto duchu mala vo Francúzsku vel'ká čast’ priemyselníkov. Popredným zástupcom tu bol Léon Harmel (1829-1915), ktorý sa z pozície vel'kého textilného továrnika zasadzoval o nové uchopenie robotníckeho bývania a aktívne sa podielal aj na zavádzaní robotníckych sporitel'ní, biblických škôl a spolkov [Gueslin 1992: 203].

Termín paternalizmus sa na rozdiel od patronage začal používat’ až v realite konca 19. storočia a bol spájaný s pomerne hanlivými konotáciami. Presadzovali ho čoraz silnejšie odborové organizácie, ktoré sa snažili zdiskreditovat konanie vlastníkov. Majitelov tovární tak portrétovali až ako feudálnych pánov, vykonávajúcich moc na svojom léne a redukujúcich robotníkov na svojich poddaných či nevolníkov [Noiriel 1988: 18].

\section{Definovanie paternalizmu}

Čo však definovalo paternalizmus v samotnom priemyselnom rámci? Historici venujúci sa francúzskemu priemyslu charakterizovali paternalizmus v dvoch základných 
smeroch. Historička Michelle Perrot obmedzila užitie označenia paternalizmus len na podmienky, ktoré by sme našli v malých textilných fabrikách so zamestnávatelom fyzicky prítomným v továrni, vztahmi založenými na modele rodiny a robotníctve, ktoré takýto integrujúci prístup vnímalo až ako isté privilégium. Pomery, ktoré sa takto vyvinuli medzi vlastníkom a robotníkmi, boli chápané ako prirodzené a legitímne nakolko odkazovali k tradičným formám správy a kontroly v rurálnych spoločnostiach.

Paternalizmus však nemusí byt’ obmedzený len na malé rodinné podniky počínajúcej industrializácie. Ako ukázali vo svojich výskumoch Peter Stearns, či Gérard Noiriel [Stearns 1978; Noiriel 1986] paternalizmus sa vel'mi dobre dokázal uplatnit aj vo vel'kých baniach či oceliarenských podnikoch, kde podmienky zadefinované Michelle Perrot neboli nijak naplnené. Priemyselný paternalizmus tak nebol len sériou inštitúcií, ktoré zamestnávatel' ponúkal robotníkom ako akýsi doplnok ku mzde. Vo vel'kých firmách predstavoval jednoznačne manažérsku stratégiu a set techník používaných k vytvoreniu previazaných emocionálne-hierarchických väzieb. Nezanedbatelné boli aj finančné náklady na ich zavedenie a udržiavanie zo strany vlastníkov. Bývanie, penzijné fondy, poistenie, závodné obchody, školy, kostoly a nemocnice, ktoré boli súčastou priemyselných komplexov, a snažili sa o podporu komunitného života si vyžadovali pravidelné investície. Podnikatelia do tejto oblasti investovali nemalé prostriedky. Na konci 19. storočia mali vel'ké spoločnosti ako Le Creusot alebo Anzin vynakladat z každých desiatich frankov zaplatených na mzdách jeden frank na vlastný sociálny systém. Pre robotníkov táto prax predstavovala akési doplnkové nemonetárne príjmy, ktoré však boli neprenosné a náležali robotníkovi, len pokial' bol zamestnancom firmy [Reid 1985: 583].

Z chronologického hladiska siahali počiatky uplatňovania prístupov priemyselného paternalizmu do sedemdesiatych rokov 19. storočia a jeho pomyslenou zlatou epochou bolo medzivojnové obdobie. Realita po druhej svetovej vojne následne priniesla jeho pomalý ústup na ceste $\mathrm{k}$ úplnému vytrateniu sa v merítku velkých podnikov v šest’desiatych rokoch 20. storočia [Noiriel 1988: 27]. Jednotiaci prvok predstáv paternalistického prístupu v každom z týchto ponímaní zastupovalo naprieč desatročiami silné metaforické chápanie zamestnávatela ako otca, a celej fabriky ako rodiny. Klúčové k pochopeniu priemyselného paternalizmu je tak nájdenie odpovede na otázku ako táto metafora funguje v podmienkach kde zamestnávatel' (vlastník) nie je jediným nadriadeným či manažérom v danom podniku [Reid 1985: 580-581].

K osvojeniu paternalistických prístupov vel'kými priemyselnými koncernami došlo v podmienkach konca 19. storočia, kedy sa za Tretej republiky prudko rozvíjalo sociálne zákonodarstvo a silneli i odborové organizácie. Francúzsky priemysel bol však čoraz viac konfrontovaný s nestabilitou pracovnej sily, poklesom natality a nedostatkom kvalifikovaných robotníkov. Rozvoj železníc a prepájanie jednotlivých regiónov viedlo zároveň k zvyšujúcej sa mobilite a k vytváraniu jednotného národného trhu práce. Do hry vstupovali aj nový priemyselný aktéri v podobe celých odvetví priemyslu (chemický, strojárenský, automobilový). Velký zamestnávatelia v metalurgii či v baníctve tak museli hladat nové cesty $\mathrm{k}$ udržaniu a získaniu pracovnej sily.

Gérard Noiriel, ktorý sa zameral na analýzu priemyselného paternalizmu vo vel'kých železiarenských a oceliarskych komplexoch, upozornil na jeho tri silne charakteristické znaky. V prvom rade sa tento prístup mal snažit’ odpovedat’ na chronický deficit pracovnej sily. O robotníctvo sa vlastník hodlal postarat’ v celistvosti pričom jeho cielom bolo 
dokonca zabezpečit d’alšiu reprodukciu pracovnej sily prostredníctvom siete zariadení od ubytovania cez školy, penzijné fondy až k nemocniciam. Takáto stabilizácia až fixácia robotníctva sa ukázala ako značne úspešná. Na prelome storočí pracovala napríklad v podniku Le Creusot jedna tretina zamestnancov dlhšie než 20 rokov a jedna osmina dokonca viac než 30 rokov. Medzi zamestnancami by sa rovnako našlo niekol'ko generácií tej istej rodiny či blízke príbuzenské prepojenie. Na jednej dielni pracovali často bratranci, strýkovia či kmotrovia [Reid 1985: 602]. Výrazným znakom priemyselného paternalizmu bola aj snahu o disciplináciu pracovnej sily. Tento prístup mal predstavovat akúsi ochranu pred šíriacim sa socializmom, mal zamedzovat proletarizácii robotníkov, predchádzat' konfliktom a obmedzovat’ silu odborov i nátlaku štrajkov. Paternalizmus zároveň prichádzal s vlastnou víziou solidarity, ktorá sa formovala na linke medzi zamestnávatelom a robotníkmi a nie medzi robotníkmi navzájom [Debouzy 1988: 6-7].

Uplatňovaním prístupov priemyselného paternalizmu dochádzalo $\mathrm{k}$ posilňovaniu autority nielen vlastníka, ale čoraz viac i inžinierov, predákov a iných vedúcich, ktorí samotného vlastníka medzi robotníctvom sprítomňovali v každodennom továrenskom kolobehu. Rozšírenie tejto siete bolo nevyhnutné nakol'ko vlastník vel'kých priemyselných podnikov nedokázal byt nepretržite prítomný v samotnej továrni. Legitimita vlastníkov bola posilňovaná distribúciou pomoci v krízových obdobiach, ale aj darov, oblečenia či mäsa počas sviatkov a osláv. Závodné bývanie, školy či zdravotná starostlivost̉ a poistenie vytvárali celý sociálny oporný systém, ktorý bol doplnený organizovaním osláv odchodu do penzie, predávania diplomov z učňovských škôl či športovými podujatiami. Tie mali podporovat' komunitného ducha, ako aj plnú oddanost' podniku. Motivácie mnohých vlastníkov vychádzali často z potreby zavŕšenia vlastného poslania, pričom vel'ká čast’ z nich akcentovala silne náboženský rozmer starostlivosti o potrebných, ako aj morálne záväzky plynúce z vlastníctva. Katolícka či kalvínska morálka tak stála vo Francúzsku za rozvojom podnikovej politiky v oblasti bývania a vzdelávania, ako i za chápaním podniku ako jednej vel'kej rodiny. K rozšíreniu prístupov paternalizmu zásadne prispievali významné osobnosti z regiónov, stúpenci myšlienok Frédérica Le Playa, ktorí v snahe čelit’ sporom so socialistami a robotníckym hnutím zavádzali v továrňach modely vztahov, ktoré mali humanizovat ale zároveň aj racionalizovat celý tento priestor. Paternalistické prístupy vykazovali zároveň aj istú mieru odlišností líšili sa regionálne ako aj podla druhu priemyslu a potrieb daného odvetvia. Dôležitú úlohu zohrávalo angažovanie sa vlastníkov v oblasti politiky. Mnohí priemyselníci zastávali súbežne i úrad starostu či boli poslancami, a tak museli zohladňovat’ aj svoje politické renomé či silu slobodný volieb [Chalre 1991: 236]. Tvrdý liberalizmus konca 19. storočia podla značnej časti vlastníkov mohol vyprovokovat’ socialistické revolúcie a dlhodobá nespokojnost̉ robotníctva rozpútat’ až občiansku vojnu, podobnú udalostiam parížskej komúny, ktorá stále silno rezonovala v prostredí priemyselníkov ako záchvev nestability a anarchie. Cielom tak malo byt’ vytvorenie atmosféry vzájomnej dôvery a spokojnosti robotníctva, ktoré by si cenilo výhod poskytovaných zo strany zamestnávatelov [Chalre 1991: 308]. Odpoved' čoraz mohutnejšieho robotníckeho hnutia bola jasná, v paternalizme videli robotníci hlavne d’alší nástroj k vykoristovaniu pracujúcich a obmedzovaniu ich vlastných slobôd.

V paternalistických snahách továrnikov sa zrkadlila aj istá nedôvera až opozícia proti štátu a silnejúcim snahám o zasahovanie a definovanie sociálnej politiky. Rozsiahle priemyselné koncerny vychádzali z predpokladu, že podmienky v podnikoch i vztahy 
k robotníctvu si musia definovat sami a ich sociálna citlivost’ a vnímavost potrieb robotníctva je dostatočná.

\section{Výzvy priemyselného paternalizmu}

Velkou skúškou pre podniky a to čo by sme súčasným termínom označili manažment ludských zdrojov bola vo Francúzsku situácia po prvej svetovej vojne, kedy priemyslu chýbali zásadné počty kvalifikovaných i nekvalifikovaných robotníkov. Podla odhadov prvá svetová vojna pripravila krajinu o 3,3 milióny obyvatel’ov. V roku 1919, ked' francúzsky priemysel zahájil svoju obnovu, mu chýbalo viac než 10 \% robotníkov [Noiriel 2011: 125]. Obdobie po prvej svetovej vojne zároveň charakterizoval masívny rozvoj nových odvetví a priemyselných regiónov. V snahe o získanie kvalifikovaných robotníkov tak dochádzalo až k organizovaniu náborových výprav do starých priemyselných oblastí, kde aj vd’aka paternalistickým snahám existovala vel'ká zásoba kvalifikovanej pracovnej sily. Paternalistický model vztahov a siet’ služieb (závodné bývanie, školy, zdravotná starostlivost', poistenie), podrobovaný silnej kritike zo strany odborov pred prvou svetovou vojnou tak v krízovom povojnovom období nabral pomyslený druhý dych a rozšíril sa naprieč regiónmi a typmi priemyslu. Nestratil svoje staré bašty v tažkom priemysle či baniach a dokonca získal uplatnenie v rozvíjajúcej sa automobilovej či elektrotechnickej výrobe.

Výhody, ktoré tento prístup prinášal, však neboli rovnaké pre všetkých robotníkov. Jednalo sa o selektívnu politiku uplatňovanú voči kvalifikovaným robotníkom. Na pristahovalcov pracujúcich vo vel'kých počtoch hlavne v tažkom priemysle a uholných baniach sa prístup priemyselného paternalizmu vztahoval len okrajovo. Nešlo o početne zanedbatel'nú skupinu. V priebehu jedného desatročia rámcujúceho povojnovú regeneráciu a prepuknutie vel'kej hospodárskej krízy (1921-1931) prišlo do Francúzska za prácou milión zahraničných robotníkov. S rodinami táto skupina predstavovala až dva milióny ludí. V roku 1930 tvorili zahraničný robotníci až 15 \% z celkového počtu robotníctva vo Francúzsku. Prichádzajúci cudzinci nachádzali prácu v t’ǎ̌kých až odpudivých podmienkach, ktoré boli opustené domácimi pracovnými silami [Noiriel 2011: 133]. Cudzinci zamestnávaní ako pomocné pracovné sily boli pre vel'ké priemyselné podniky síce nevyhnutnostou, nepredstavovali ale nenahraditelný element. Vdaka racionalizácii náboru, ako aj pomoci zo strany štátu dokázali špeciálne železiarne a bane naberat dostatok mladých, zdravých mužov z Talianska, Pol’ska či z Československa. Od roku 1924 bol za týmto účelom zriadený aj špeciálny úrad Société générale d’immigration (V̌̌eobecná spoločnost' pre pristahovalectvo), ktorý mal na starost’ prípravu celého náboru ako aj prerozdelovanie pracovnej sily do regiónov. Išlo o inštitúciu prepájajúcu vedenie podnikov a štátnu administratívu, ktorá zabezpečila bilaterálne zmluvy s jednotlivými krajinami. Svoje pobočky mala aj v Prahe a Bratislave, bratislavská sa zameriavala na nábor polnohospodárskych síl a pražská na priemyselné robotníctvo. Všetci žiadatelia o prácu vo Francúzsku prechádzali profesnou a lekárskou prehliadkou. Konečný výber, ako aj stanovenie kvót prijatých zamestnancov však závisel na francúzskych oficiálnych úradoch a zamestnávatel'ských kruhoch. V priebehu rokov 1921 až 1930 za prácou do Francúzska odišlo okolo 60000 československých občanov. K odchodu ich motivovala pomerne rozsiahla informačná kampaň, ako aj vidina lepších platových pomerov francúzskeho robotníctva. Postupne sa však aj do Československa dostávali správy o pracovných podmienkach i vztahoch aké vládli voči pracovným 
migrantom v zemi galského kohúta. Časopisy ako Vystěhovalec a Československá emigrace prinášali aj nelichotivé svedectvá o neznesitelných pracovných podmienkach, zlom ubytovaní a nedodržiavaní zmlúv [Namont 2015: 179-182].

Príprava pracovnej sily z cudziny pritom vel'ké francúzske podniky nič nestála, po príchode prispievali do systému poistenia i penzijného zabezpečenia pričom ich pozícia bola extrémne neistá. Ich pracovné zmluvy sa riadili dokonca inými právnymi zásadami a mnohokrát neboli vôbec dodržiavané. Cudzinci boli pod vel'mi silnou kontrolou štátnej administratívy i samotného podniku, ktoré výrazne obmedzovali ich osobné slobody. Mohli pracovat' len na konkrétnom mieste a pozícii a akákolvek zmena bola skoro nemožná [Noiriel 2011: 135]. K výhodám poskytovaným zo strany zamestnávatela sa dostávali len vel'mi zriedkavo - aj ked' to boli práve oni, kto bol najviac vystavený nebezpečenstvu a nestabilite priemyselnej práce. Za prácou do Francúzska ich k tomu obvykle nesprevádzali ženy ani deti, ktoré by zatažovali systém sociálnych podpôr podniku. Vedenie spoločností tak podobným nerovným nastavením prispievalo nielen k rozštiepeniu robotníctva, ale v niektorých prípadoch dokonca priamo podporovalo vyhrotenú xenofóbiu francúzskych zamestnancov [Noiriel 2011: 138-140]. Protesty proti zamestnávaniu cudzincov, ani mnohé konflikty medzi domácimi a zahraničnými robotníkmi neboli ničím výnimočným. Ich intenzita sa zároveň stupňovala priamo úmerne s výkyvmi ekonomického cyklu a nástupom hospodárskej krízy.

Systém vztahov, kompetencií a sociálneho zázemia nemenil len realitu robotníkov vo francúzskych továrňach a baniach, ale aj v ich rodinách, v postavení žien i výchove nasledujúcich generácií. Začiatkom 20. storočia došlo i pod vplyvom priemyselného paternalizmu k redefinícii postavenia a role žien v priemyselných regiónoch. Markantne sa vytrácala ich spätost' s polnohospodárstvom a nutnost' zabezpečovat' pre rodinu živobytie z vlastnej záhrady. Naopak novou prioritou sa stala starostlivost’ o domácnost' v mestskom prostredí a správa rodinného rozpočtu. Nové potreby sa odrážali aj v náraste počtu škôl a kurzov, ktoré pripravovali gazdiné a matky na ich povinnosti. V tejto oblasti sa silne uplatnila aj katolícka cirkev často krát podporovaná vedením podnikov. Ženy mali zabezpečit nielen všestranné fungovanie domácnosti, ale mali byt aj akýmisi strážkyňami morálnosti a rodinných financií, chrániace mužov pred krčmou a hazardom. Táto samozrejme nehonorovaná práca žien však prispievala k nutnosti obmedzovania výdavkov robotníckych rodín, ako aj k rastúcej podriadenosti a závislosti robotníckych žien na ich partneroch [Noiriel 1988: 32].

Podniky presadzovali rovnako silnú rodinnú politiku podporujúcu pôrodnost'. Michelin v Clermont-Ferrand zavádzal od dvadsiatych rokov znížené nájmy pre mnohopočetné rodiny, ako aj rozpracovaný systém finančných podpôr a bonusov pri narodení dietata, a následne možnosti rodinných či výživových dávok [Dumond - Gueslin 1993]. Firemné školy mali zaručit prípravu d’alších generácií skúsenej pracovnej sily, ktorá by bola plne vžitá s organizačným systémom i firemnou kultúrou. Vzdelávanie pritom neprebiehalo len v triedach, ale aj priamo v továrni pod dohladom skúsenejších robotníkov, ktorí boli prezentovaní ako morálne a technické vzory, či ako prototyp otcovstva. Vzdelávací systém hral zásadnú rolu aj pri príprave budúcich vedúcich robotníkov - predákov a zároveň ponúkal možnost̉ sociálneho výtahu pre nadané deti, ktoré mohli byt aj na náklady firmy vysielané na vysokoškolské štúdia [Reid 1985: 603]. Silnej kontrole podliehal aj spoločenský život a vol’nočasové aktivity. Športové kluby či lokálne oslavy boli financované a kontrolované zo strany vlastníkov firiem a mali za ciel' podporovat' výkonnost' a spokojnost' robotníctva. 


\section{Paternalizmus vo francúzskej historiografii}

Problém interpretácie priemyselného paternalizmu, jeho ciel’ov a nástrojov sa silne odráža i vo francúzskej historiografii venujúcej sa sociálnym, hospodárskym či politickým dejinám priemyselných oblastí. V pohlade na paternalizmus sa vykryštalizovali dva výrazné prúdy. Prvý, inšpirovaný marxistickým pohladom a foucaultovským spôsobom interpretácie sociálnej reality, chápe paternalizmus ako disciplinačný model, založený na ideologickom klame a sledujúci presadenie absolútnej kontroly nad továrenským robotníctvom. Z marxistickej perspektívy paternalizmus spochybňuje pomer medzi triedami a paternalizmus vidí ako neprirodzenú odchýlku vo vzt’ahu dvoch antagonistických skupín. Paternalizmus je v tomto prípade interpretovaný ako absolútna dominancia skoro až feudálneho typu, vtlačená do kapitalistického ekonomického rámca. Paternalizmus či jeho predchodcovia tak tvoria nástroj zamestnávatelov $\mathrm{k}$ disciplináci más robotníctva, ktoré hlavne $\mathrm{v}$ počiatkoch industrializácie nie je nijak socializované pre potreby práce v továrňach. Táto disciplinácia sa prelína s jazykom obáv o hygienické či morálne aspekty priemyselnej práce - pracovný kontakt mužov a žien, promiskuita, rozvrat rodín. Robotnícke mestečká a kolónie mali mat preto za ciel’ uviazat’ pracovnú silu na jednom mieste, zjednodušit’ celkový dohlad i kontrolu. Zároveň mali zaručit’ reprodukciu novej generácie robotníkov socializovaných prostredníctvom škôl a celkovej morálky presne pre potreby a ciele podniku. Zo závodných kolónií sa v perspektíve tohto prístupu stáva až akýsi ludský žrebčín, zásobáreň vhodných pracovných kádrov, ktoré nemusia byṫ znovu a znovu obnovované migráciou [Lamanthe 2011: 28, 29]. Paternalizmus mal v tomto výklade smerovat’ až k úplnej strate vlastnej identity robotníctva a slepému splynutiu s daným podnikom. Robotníctvo bolo prezentované až ako pomýlená obet’ systému vzdelávania a nepretržitej sociálnej kontroly vlastníkov.

Tento pohlad vysvetlujúci paternalizmus prostredníctvom disciplíny, dozoru, väznenia či kasární sa silne zrkadlil v práci Le petit travailleur infatigable: villes-usines, habitat et intimités au XIXe siècle (Malý neúnavný robotník, továrne mestá, bývanie a intimita v 19. storočí) [Murard - Zylberman 1976], venujúcej sa vytváraniu robotníckych kolónií. Ubytovanie v podobe akýchsi robotníckych kasární, ktoré bolo pre vel'kú kritiku postupne nahradzované výstavbou robotníckych mestečiek s menšími domami, malo robotníctvo silnejšie pripútat k továrni a zabezpečit’ výrobe dalšie generácie zamestnancov. Urbanistické plány vel'kých podnikov, ktoré počas niekol'kých desatročí vystavali celé mestá na zelených lúkach, sa snažili presadit vlastnú kontrolu nielen nad továrňou, ale aj nad každodennostou, rodinou a volným časom. Prístupy premýšlajúce prepájanie a vzájomné pôsobenie medzi priestorom a spoločenskou realitou sa stali pre francúzskych historikov osemdesiatych rokov značne atraktívnymi aj pod vplyvom tzv. priestorového obratu, ktorý silne rezonoval naprieč celou západnou historiografiou. Historici venujúci sa týmto presahom paternalizmu a podnikových záujmov do urbanizmu miest si zároveň uvedomovali i snahy o izoláciu robotníctva a potláčanie jeho skupinovej identity. Podobným smerom postupovali okrem spomínanej práce aj d’alší autori osemdesiatych rokov, ako aj niektoré štúdie z doby konca rokov devätdesiatych [Ewald 1986; Frey 1995; Morice 2000].

Tendencie k rozšíreniu interpretačného rámca paternalizmu nastolilo v roku 1988 tematické číslo časopisu Mouvement Social, ktorého hlavnou editorkou bola Marianne Debouzy, francúzska historička venujúca sa dejinám robotníctva a americkej histórii. 
Spolu s d’alšími šiestimi autormi predložili celú plejádu pohladov na paternalizmus nie len v európskom, ale aj mimoeurópskom priestore. Debouzy upozornila, že v paternalizme sa zrkadlia aj slabosti a obavy vlastníkov voči vysokej koncentrácii robotníkov. Starostlivost’ o pracovnú silu predstavuje v očiach zamestnávatelov jasnú racionalizačnú stratégiu, ktorá má zmierňovat napätie plynúce zo sociálnych nerovností priemyselných centier. Spoločne s d’alšími autormi sa tak Debouzy prihlásila k snahe otvorit’ otázku vzt’ahov medzi triedami i špecifík robotníckej identity. Chápanie paternalizmu ako absolútnej dominancie či manipulácie robotníctva označili autori spomínaného tematického čísla Mouvement Social za silne stereotypné. Poukázali na to, že aj v takto nastavenom rámci vztahom medzi zamestnávatelom a robotníkmi, disponovalo robotníctvo možnostou protestu či vyjednávania svojich požiadaviek. Zároveň bola zdôrazňovaná obojstrannost’ vzt’ahu medzi zamestnávatelmi a robotníkmi, kde ich pomer definuje akýsi kontrakt či zmluva, z ktorej každý z účastníkov niečo t’aží [Debouzy 1988: 11]. Autori tohto tematického čísla opakovane upozorňovali, že aj paternalistický model vztahov a správy podnikov ponúkal značnú škálu vol'nosti pre aktivity robotníctva, ktoré si zachovalo schopnosti reagovat' a protestovat'. Autorita vlastníkov bola pritom tiež vyjednávaná a podliehala premenám a tlakom zo strany štátu, samotných robotníkov i odborov.

Otázky spojené s osvojením si tohto modelu vztahov zo strany samotných robotníkov motivovali dalšie výskumy a úvahy francúzskej historiografie začiatku devätdesiatych rokov. André Gueslin bol presvedčený, že ako historik musí spochybňovat’ nepravdepodobnú tézu, ktorá jednoliato predpokladá dlhodobé podrobenie sa robotníctva disciplinačnému prístupu, ktorý by bol úplne proti jeho vôli [Gueslin 1992: 205]. Akceptovanie paternalistických prístupov malo podla Gueslina mnoho príčin. Dalo by sa vysvetlovat' jednak pretrvávajúcou tradičnou kultúrou, nespochybňovaním autorít, ako aj priestorovým rámcom velkých podnikov, ktoré vytvárali akýsi pomyslený ostrov, ktorý sa nedal lahko opustit'. Pripustit treba aj výhodnost' služieb ponúkaných zo strany zamestnávatel'ov, ktoré mohli predstavovat istý nadštandard, robotníkom skoro nedostupný mimo daného podniku.

So začiatkom nového tisícročia sa úvahy o paternalizme a jeho podobách vtelili vo francúzskej historiografii do širších transnacionálnych debát a prác, ktoré analyzujú rôzne podoby práce či vytváranie autority šéfa [Petit - Thévenot 2006; Cohen 2013]. Pomyselná jedinečnost’ modelu priemyselného paternalizmu sa tak zasadila do širšieho kontextu priemyselnej práce, riadenia a sociálnych dejín.

\section{Záver}

Paternalistické prístupy v sebe skrývali istú vnútornú dvojakost’ a protichodnost'. $\mathrm{Na}$ nové podmienky vel'kej priemyselnej výroby dokázali adaptovat tradičné formy kontroly, charakteristické častokrát ešte pre pred-industriálne obdobie. Ich zavádzanie prebiehalo pritom v duchu nových racionalizačných opatrení, manažérskych prístupov či zákonných úprav. Zároveň v sebe prepájali emancipačné a disciplinačné aspekty prístupu k robotníctvu. Patronage industriel tak predstavoval komplikovanú siet záujmov a obojstranných záväzkov. Robotník bol presvedčený, že dobrodenie, ktoré sa mu dostáva je prepojené s prosperitou vlastníka. Ten si zároveň uvedomoval svoju lokálnu dôležitost', ako aj význam svojich materiálnych a morálnych povinností voči zamestnancom [Lamanthe 2011: 34-36, 
71-74]. Priemyselný paternalizmus so svojimi prístupmi a službami sa zároveň priamo podielal na procese socializácie robotníctva a jeho adaptácii na nové podmienky priemyselnej práce a bývania v továrenských mestách. Z pracovnej sily pochádzajúcej z vidieka či cudziny tak vytváral továrenské robotníctvo [Gueslin 1992: 203-207].

Úvahy, ktoré prebiehali okolo priemyselného paternalizmu vo francúzskej historiografii môžu byt do vel'kej miery bádatel'skou výzvou aj pre českú a slovenskú produkciu, ktorá s rôznymi podobami paternalizmu pracuje skôr implicitne a niekedy dokonca až vágne. Akékolvek angažovanie sa podnikatel’ov v oblasti ubytovania, školstva či zdravotnej starostlivosti je tak často vydávané za paternalistické chovanie bez toho, aby boli premýšlané kritéria, ciele či podoba podpory. Rozsiahla priemyselná činnost’ hlavne v rámci českých zemí pritom ponúka nesmierne široký priestor $\mathrm{k}$ týmto úvahám v prostredí Vítkovíc, Plzne, či rôznych centier textilného priemyslu. I v prípade firmy Bata, kde sa paternalistické motívy považujú za niečo samozrejmé [Jemelka - Ševeček 2016], sme konfrontovaný s tým, že sa nad týmto pojmom ani jeho naplñaním v špecifických podmienkach Zlína a dalších miest nikto špeciálne nezamýšla. Priemyselný paternalizmus a sociálne služby zabezpečované zo strany podnikov pritom môžu nabádat' k množstvu rozdielnych interpretácií. Vidiet’ v nich môžeme predchodcu prístupov, ktoré sa rozvinuli naplno v totalitných režimoch 20. storočia, ale aj myšlienok, ktoré našli uplatnenie v súčasnom ponímaní sociálneho štátu. Ďalší pohlad podnecuje chápanie priemyselného paternalizmu ako manažérskej stratégie závislej na množstve premenných, ktorá je definovaná hlavne vzájomnou previazanost' a závislostou všetkých aktérov.

Aj napriek tomu, že prístupy charakteristické pre priemyselný paternalizmus sa začali $\mathrm{z}$ podnikov úplne vytrácat $\mathrm{v}$ období šest'desiatych rokov v nadväznosti na zásadné premeny výroby, automatizáciu, posilnenie vplyvu štátu i odborov, je zaujímavé sa zamýšlat nad pokračovaním či dalšou adaptáciou týchto modelov. Domnievam sa, že nejde len o prístup, ktorý zostáva uväznený v hospodárskych a sociálnych reáliách 19. a 20. storočia. V istých bodoch pretrval do dnešných dní. Moderné manažérske techniky sa snažia rovnako ako továrnici 19. storočia o lojálnost' zamestnancov a vztahy založené na dôvere. Pomyslenými dedičmi priemyselného paternalizmu sú aj mnohé benefity známe z vel'kých korporácií. Predstavujú tiež nemonetárne výhody, ktoré majú zabezpečit’ vyššiu prítažlivost’ danej spoločnosti v očiach zamestnanca a rovnako prispiet' $\mathrm{k}$ jeho spokojnosti a zotrvaniu na pracovnej pozícii. Výhody rastú úmerne s nedostatkom vhodných adeptov na konkrétnu pracovnú pozíciu a sú kompetitívnym prvkom vyjednávania.

\section{Podakovanie}

Tento text je výsledkem standardního projektu č. 18-03921S, Sociální otázka in situ: sociální politika průmyslových podniků v českých zemích, 1879-1914, který podpořila Grantová agentura České republiky.

\section{Literatúra}

Cohen, Yves [2013]. Le siècle des chefs. Une histoire transnationale du commandement et de l'autorité (1890-1940). Paris: Éd. Amsterdam.

Debouzy, Marianne [1988]. Permanence du paternalisme?. Le Mouvement social 144: 3-16. 
Doria, Corinne [2014]. Aux origines du paternalisme industriel . Léducation industrielle dans la pensée physiocratique et dans la Société d'encouragement pour l'industrie nationale. Les Etudes Sociales 159: 11-28.

Dumond, Lionel - Gueslin, André [1993]. Michelin, les hommes du pneu: les ouvriers Michelin, à Clermont-Ferrand, de 1889 à 1940. Paris: Editions de l'Atelier.

Ewald, François [1986]. L'Etat providence. Paris: Grasset.

Frey, Jean-Pierre [1995]. Le rôle social du patronat: Du paternalisme à l'urbanisme. Paris: Editions L'Harmattan.

Gueslin, André [1992]. Le paternalisme revisité en Europe occidentale (seconde moitié du XIXe siècle, début du XXe siècle). Genèses. Sciences sociales et histoire 7 (1): 201-211.

Charle, Christophe [1991]. Histoire sociale de la France au XIXe siècle. Paris: Le Seuil.

Jemelka, Martin - Ševeček, Ondřej [2016]. Tovární města Batova koncernu: evropská kapitola globální expanze. Praha: Academia.

Lamanthe, Annie [2011]. Les métamorphoses du paternalisme: histoire, actualité et dynamiques. Paris: CNRS.

Le Play Frédéric [1867]. La Réforme Sociale en France. Paris.

Morice, Alain [2000]. Recherches sur le paternalisme et le clientélisme contemporains: méthodes et interpré-tations. Anthropologie sociale et ethnologie. Paris: Ecole des Hautes Etudes en Sciences Sociales.

Murard, Lion - Zylberman, Patrick [1976]. Le petit travailleur infatigable: villes-usines, habitat et intimités au XIXe siècle. Paris: Recherches.

Namont, Jean-Philippe [2015]. Československá kolonie. Dějiny české a slovenské emigrace ve Francii (19141940). Praha: Academia.

Noiriel, Gérard [1988]. Du „patronage“ au „paternalisme“: la restructuration des formes de domination de la main-d'œuvre ouvrière dans l'industrie métallurgique française. Le Mouvement social 144: 17-35.

Noiriel, Gérard [(1986) 2011]. Les ouvriers dans la société française XIXe-XXe siècle. Paris: Éditions du Seuil.

Petit, Héloïse - Thévenot, Nadine [2006]. Les nouvelles frontières du travail subordonné. Approche pluridisciplinaire. Paris: La Découverte.

Reid, Donald [1985]. Industrial Paternalism: Discourse and Practice in Nineteenth-Century French Mining and Metallurgy, Comparative Studies in Society and History 27 (4): 579-607.

Savoye, Antoine [1994]. Les débuts de la sociologie empirique: études socio-historiques, 1830-1930. Paris: Méridiens Klincksieck.

Savoye, Antoine - Cardoni, Fabien [2007]. Frédéric Le Play: parcours, audience, héritage. Paris: École des mines de Paris.

Stearns, Peter [1978]. Paths to authority: the middle class and the industrial labor force in France, 1820-48. Urbana: University of Illinois Press.

Štofaník, Jakub [2017]. Medzi krízom a kladivom: recepcia sociálneho myslenia v katolíckej cirkvi v prvej polovici 20. storočia. Praha: Filozofická fakulta Univerzity Karlovy.

Jakub Štofaník, historik a vedecký pracovník Masarykova ústavu a Archivu AV ČR. Vo svojich výskumoch sa venuje sociálnym, náboženským a kultúrnym dejinám 19. a 20. storočia $v$ komparatívnej perspektíve. 